\author{
Katarzyna PIETRUCHA-URBANIK ${ }^{1}$ \\ Justyna KARNAS ${ }^{2}$
}

\title{
ASSESSMENT OF WATER NETWORK FUNCTIONING ON THE BASIS OF WATER LOSSES
}

\begin{abstract}
In the paper the analysis of water network functioning on the basis of water losses occurring in the exemplary water supply system is presented. Using the received operational data the balance of water production was shown, the individual water consumption was calculated, the basic indicators of water losses and the indicators of network hydraulic load were established, which referred to the values recommended, among others, by the American Water Works Association. On the basis of these indicators, the assessment of the state of tested water supply system was performed. The unitary volume indicators related to water losses are at the constant level. The unitary indicator of water losses for the years 2007-2015, on average, amounted to approx. $108 \mathrm{dm}^{3} \cdot \mathrm{inh}^{-1} \cdot \mathrm{d}^{-1}$, the unitary indicator of water supplied into network takes values from $459,1 \mathrm{dm}^{3} \cdot \mathrm{inh}^{-1} \cdot \mathrm{d}^{-1}$ in 2007 to $402.9 \mathrm{dm}^{3} \cdot \mathrm{inh}^{-1} \cdot \mathrm{d}^{-1}$ in 2015 , which means the decrease of approx. $12 \%$. The unitary indicator of sold water is in the range from 288,9 to $419,5 \mathrm{dm}^{3} \cdot \mathrm{inh}^{-1} \cdot \mathrm{d}^{-1}$. The infrastructure leakage index ILI, according to the criteria of World Bank Institute Banding System for developing countries, estimates the state of water supply system as good. The value of the ILI index for the analysed water supply system corresponds to national trends, which range from 3,13 to $16,52[3,8]$.
\end{abstract}

Keywords: water supply, water losses, water losses indicators

\section{Introduction}

Aiming to reduce water losses and rational water management is a priority objective of each water company. In order to reduce the volume of water losses every year the water company takes new actions to eliminate all controlled and uncontrolled water losses $[1,8,10]$. Such action may include the introduction of continuous monitoring of water losses, conducting a detailed analysis of water consumption by consumers, as well as research and assessment of indicators showing the network state and giving a signal to take appropriate action $[3,4,7,9]$.

\footnotetext{
${ }^{1}$ Autor do korespondencji/corresponding author: Katarzyna Pietrucha-Urbanik, Politechnika Rzeszowska, al. Powstańców Warszawy 6, 35-959 Rzeszów, tel. 17 8651703, kpiet@prz.edu.pl

2 Justyna Karnas, Politechnika Rzeszowska
} 
At the end of 2015 the water supply system in examined city formed a network of distributional and mains pipelines with a total length of 212,1 kilometres. During the years 2001-2015, on average, 27,81 km of main network and $166,32 \mathrm{~km}$ of distribution network operated and in years 2007-2015 5571 water supply connections were used. It was also found that at the end of 15 analysed years the total length of the main water supply decreased by almost $27 \%$. From 2001 to 2011 this value was constant and over the years decreased every year, on average, by $13,55 \%$. The distribution network is characterized by high growth, from 2001 to 2015 a total length of 140,5 kilometres increased by $49,9 \mathrm{~km}$ which gives each year increase by, on average, about $4 \%$. In the case of water supply connections, from 2007 to 2015 their number increased by 803 units.

Analysing the material structure of water supply network, it can be concluded that a dominant material of which the largest part of the water pipes is made is grey cast iron, then PVC and steel. The smallest group are pipes made of asbestoscement, which, however, are gradually exchanged for pipes made of other materials.

The value of water production for the purposes of households in the analysed period is still at almost the same level. There was not any significant decrease or increase of this value over the years. The difference is not less or more than $4 \%$ compared to the previous year. The increasing fall in water consumption was observed and this trend is not only in the examined city but in all Polish cities. This fact is, among others, caused by the increasing awareness of water users of water resources and the significant increase in the price of water per $\mathrm{m}^{3}$.

To analyse the magnitude of water losses in the water network the indicators developed on the basis of annual balance were used and the water losses were described by determining the indicators recommended by the International Water Association (IWA) [2].

\section{Determination of water losses}

To calculate water losses some data are used, their list and indications are presented in Table 1 [12].

Table 1. Summary of basic parameters to determine water losses acc. to IWA

Tabela 1. Zestawienie podstawowych parametrów do wyznaczenia strat wody według IWA

\begin{tabular}{|ll|l|}
\hline & Specification & \multicolumn{1}{|c|}{ Explanation } \\
\hline$\bullet$ & $V_{s} ;$ & Water supplied into the network \\
- & $V_{o w} ;$ & Water used for own needs of water network \\
- & $V_{S w} ;$ & Sold water \\
- & $V_{w s} ;$ & Water losses \\
- & $L_{M} ;$ & Length of mains \\
- & $L_{\mathrm{D}} ;$ & Length of distribution network \\
- & $L_{M+D} ;$ & Total length of network (mains and distribution network) \\
- & $L_{P W} ;$ & Length of water supply connections \\
- & $P W$. & \\
\hline
\end{tabular}


In the Figure 1 the balance of water production in 2007-2015 was presented.

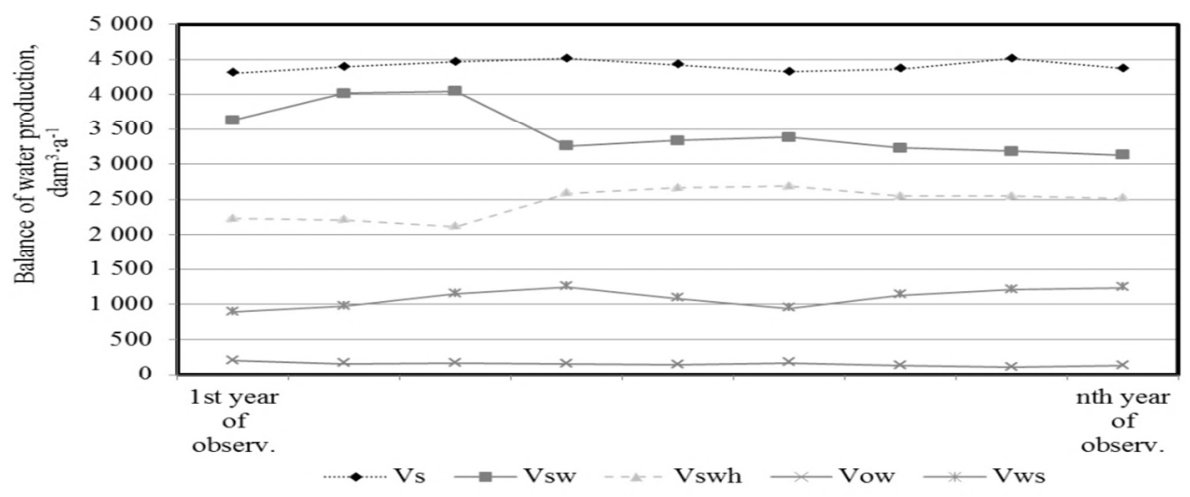

Fig. 1. Balance of water production, where $V_{s w h}$ is water sold to households (other indications as in Table 1)

Rys. 1. Bilans produkcji wody, gdzie $V_{s w h}$ - woda sprzedana gospodarstwom domowym (pozostałe oznaczenia jak w Tab. 1)

In the Figure 2 the length of individual sections of the network in 20072015 was presented.

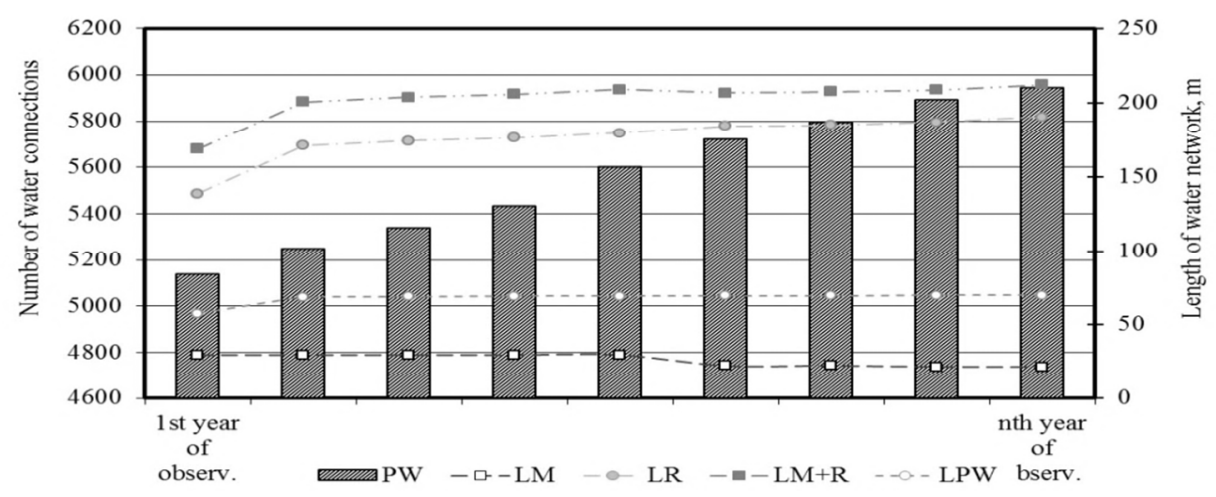

Fig. 2. The lengths of the individual sections of the water supply system in 2007-2015 (indications as in Table 1)

Rys. 2. Długości poszczególnych odcinków sieci wodociągowej w latach 20072015 (oznaczenia jak w Tabeli 1)

The assessment of actions taken to reduce water losses in water supply system can be performed using the ILI index, determined as the quotient of the volume losses by the indicator of unavoidable annual real losses (UARL) defined as: 


$$
U A R L=\left[18 \cdot\left(L_{M}+L_{D}\right)+25 \cdot P W+0,8 \cdot L_{P W}\right] \cdot 0,365 \cdot p,\left[m^{3} \cdot a^{-1}\right]
$$

where $p$ is the mean pressure in the analysed zone and 0,365 is the conversion factor, other explanations are given in Table 1.

Less strict categories of the $I L I$, according to the recommendations of AWWA, are as follows $[5,6]$ :

- $I L I \leq 3,0$ - very good state;

- 3,0<ILI $\leq 5,0$ - good state;

- 5,0<ILI $\leq 8,0$ - weak state;

- $I L I>8,0$ - unacceptable state.

While taking into account the categories of WBI Banding System for the developing countries, the range of the $I L I$ is as follows:

- $I L I \leq 4,0$ - very good state;

- 4,0<ILI $\leq 8,0$ - good state;

- $8,0<I L I \leq 16,0$ - weak state;

- $I L I>16,0$ - unacceptable state.

In order to determine the unitary real loss indicator the following types of that indicator were distinguished - the $R L B_{1}$ indicator, defined by the formula 2 (when the number of water supply connections per each $\mathrm{km}$ of network is less than 20 ) and the $R L B_{2}$ indicator, determined by the formula 3 (where the number of connections is equal or higher than 20 per km of network) [12]:

$$
R L B_{1}=\frac{V_{w s}}{L_{M+D} \cdot 365},\left[\mathrm{~m}^{3} \cdot \mathrm{km}^{-1} \cdot \mathrm{d}^{-1}\right]
$$

or

$$
R L B_{2}=\frac{V_{w s} \cdot 1000}{L_{P W} \cdot 365},\left[\mathrm{dm}^{3} \cdot \mathrm{km}^{-1} \cdot \mathrm{d}^{-1} \cdot \text { water connection }\right]
$$

In turn, the indicator of non-revenue water basic $(N R W B)$ was determined as the quotient of the difference of water supplied into network and sold water by water supplied into network.

Calculated indicators of water losses are presented in Fig. 3. 
a)
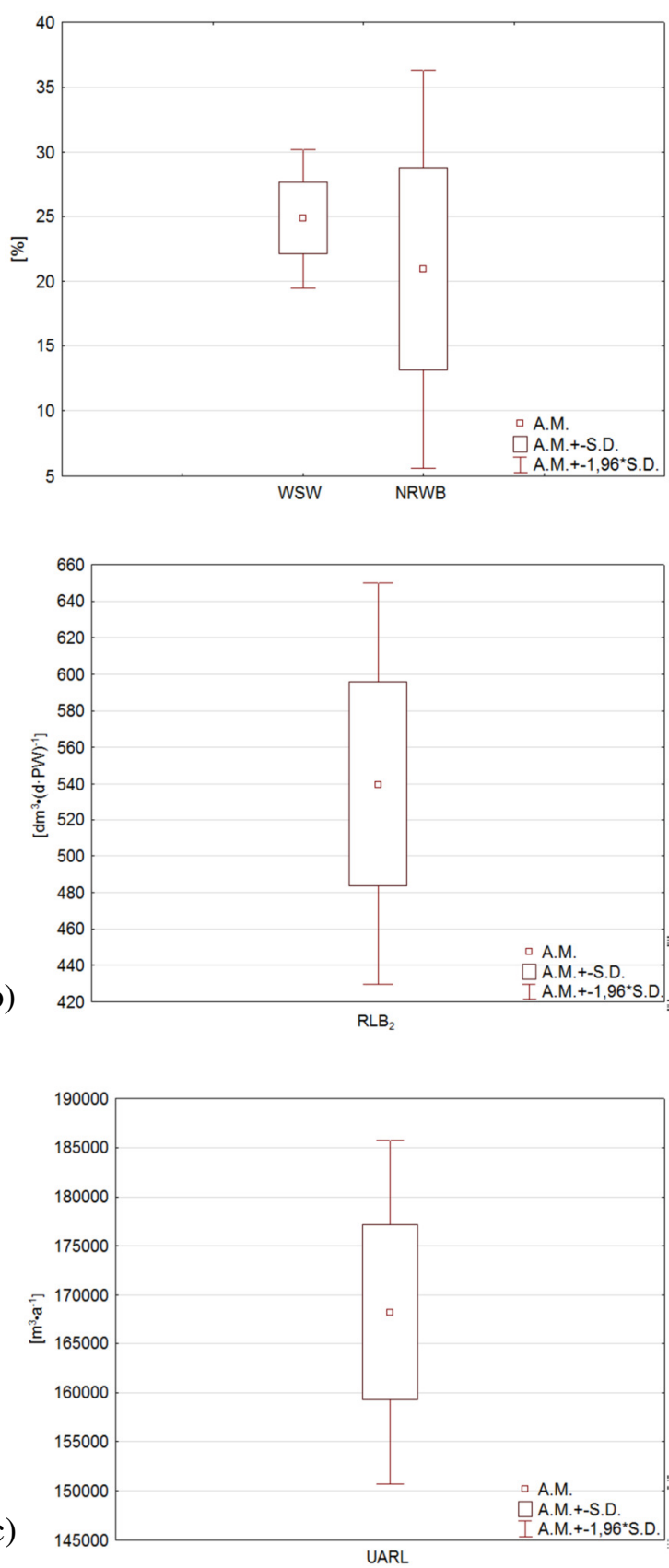

Fig. 3. Descriptive statistics of water losses indicators in 2007-2015 Rys. 3. Statystyki opisowe wskaźników strat wody w latach 2007-2015 


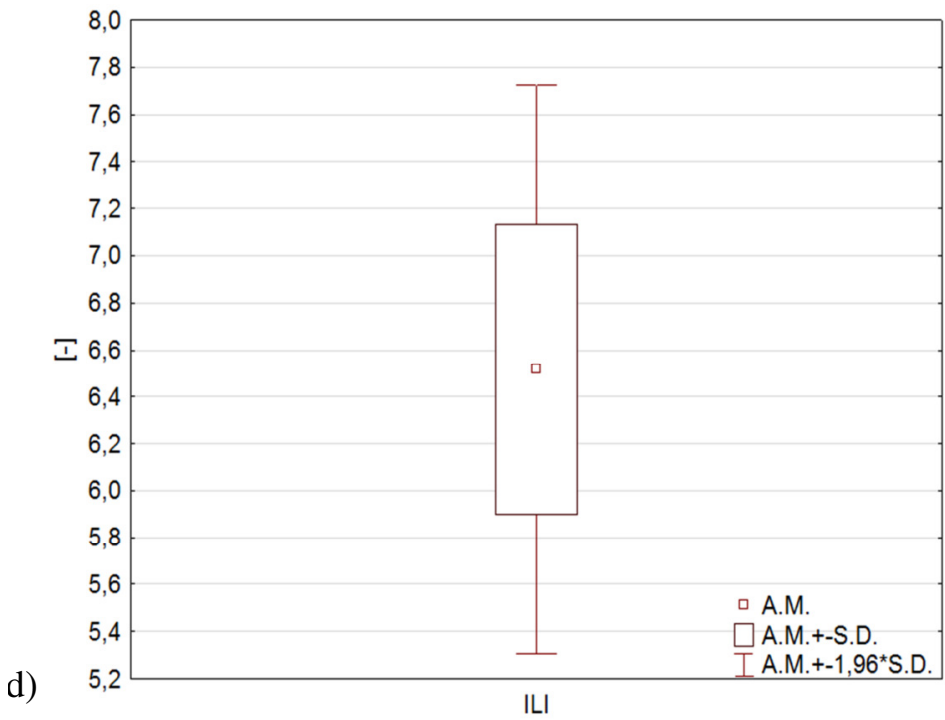

Fig. 3. Descriptive statistics of water losses indicators in 2007-2015 (c.d.)

Rys. 3. Statystyki opisowe wskaźników strat wody w latach 2007-2015 (cont.)

The determined parameters for water losses have variable tendency, for the ILI index, in the last year of analysis, there was an increase of $15 \%$.

To calculate unitary water consumption the characteristic parameter was calculated according to the formulas presented in Table 2.

Table 2. Calculation of individual indicators of water consumption and losses (indications as in Table 1)

Tabela 2. Zestawienie jednostkowych wskaźników zużycia oraz strat wody (objaśnienia jak w Tabeli 1)

\begin{tabular}{|c|c|c|}
\hline Specification & Equation & Unit \\
\hline Water supplied into network & $\mathrm{q}_{\mathrm{s}}=\left(\mathrm{V}_{\mathrm{s}} \cdot 1000\right) /(\mathrm{inh} \cdot 365)$ & \multirow{6}{*}[\mathrm{dm}^{3}\cdot\mathrm{inh}^{-1}\cdot\mathrm{d}^{-1}]{} \\
\hline Sold water & $\mathrm{q}_{\mathrm{sw}}=\left(\mathrm{V}_{\mathrm{sw}} \cdot 1000\right) /(\mathrm{inh} \cdot 365)$ & \\
\hline Water sold to households & $\mathrm{q}_{\mathrm{wsh}}=\left(\mathrm{V}_{\mathrm{wsh}} \cdot 1000\right) /(\mathrm{inh} \cdot 365)$ & \\
\hline Water losses & $\mathrm{q}_{\mathrm{ws}}=\left(\mathrm{V}_{\mathrm{ws}} \cdot 1000\right) /(\mathrm{inh} \cdot 365)$ & \\
\hline Water used for own needs & $\mathrm{q}_{\mathrm{ow}}=\left(\mathrm{V}_{\mathrm{ow}} \cdot 1000\right) /(\mathrm{inh} \cdot 365)$ & \\
\hline Nonprofit water & $\mathrm{q}_{\mathrm{nw}}=\left(\mathrm{V}_{\mathrm{s}}-\mathrm{V}_{\mathrm{sw}}\right) /(\mathrm{inh} \cdot 365)$ & \\
\hline $\begin{array}{l}\text { Hydraulic loading rate per unit } \\
\text { for water supply network }\end{array}$ & $\mathrm{q}_{\mathrm{o}}=\mathrm{V}_{\mathrm{s}} /\left(\mathrm{L}_{\mathrm{M}+\mathrm{D}} \cdot 365\right)$ & \multirow{2}{*}[\mathrm{m}^{3}\cdot\mathrm{km}^{-1}\cdot\mathrm{d}^{-1}]{} \\
\hline $\begin{array}{l}\text { Water loss rate per unit for the } \\
\text { entire length }\end{array}$ & $\mathrm{q}_{\mathrm{wsL}}=\mathrm{V}_{\mathrm{ws}} /\left(\mathrm{L}_{\mathrm{M}+\mathrm{D}} \cdot 365\right)$ & \\
\hline
\end{tabular}

In the Figures 4 and 5 the calculated unitary water loss indicators and the unitary hydraulic load indicators were shown. 


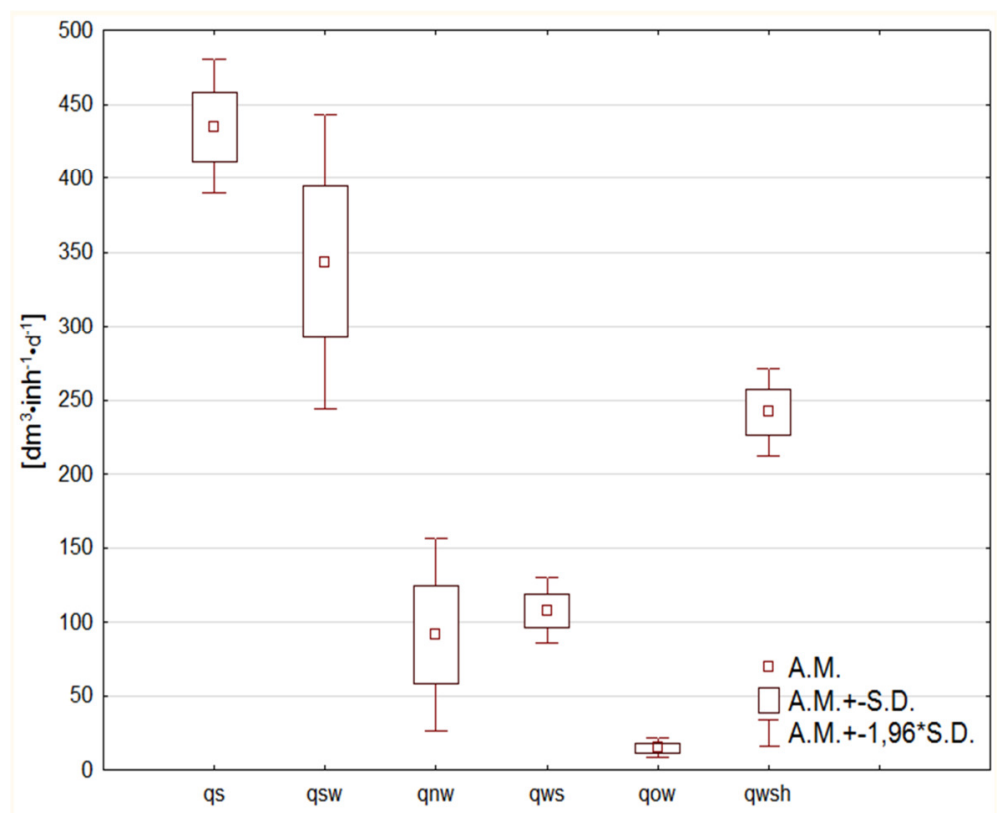

Fig. 4. Unitary water loss indicators in 2007-2015

Rys. 4. Jednostkowe wskaźniki strat wody w latach 2007-2015

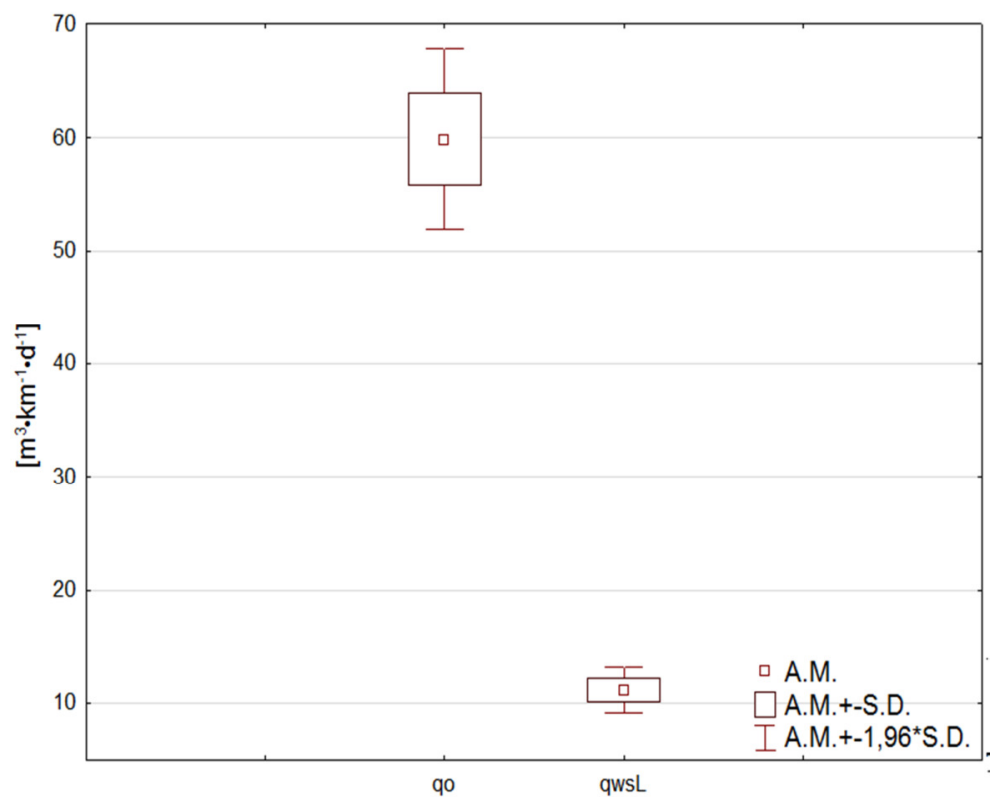

Fig. 5. Unitary hydraulic load indicators in 2007-2015

Rys. 5. Wskaźniki jednostkowego obciążenia hydraulicznego sieci w latach 2007-2015 


\section{Discussion of results}

Referring to the results of the analysis of water losses it was found that water losses which are the ratio of the volume of water losses to the amount of water supplied into the water supply network, in each of the years covered by the analysis, $2007-2015$, are in the range from $20,73 \%$ to $28,29 \%$.

Determined unitary water loss indicators and indicators of the unitary hydraulic load show a downward trend and in the last year of analysis reached the lowest value compared to the previous years of the analysis.

In order to assess water losses in water network the infrastructure leakage index $I L I$ was, among others, calculated. For the last nine years it is in the range of 5,48 to 7,46. This indicator shows how many times the real water losses exceed the unavoidable losses. Comparing the results of the ILI index with aforementioned criteria it was found that according to the IWA criteria in all analysed years the state of water supply system in the city is unacceptable. Taking the same index and referring it to the WBI criteria for developing countries this state is good, referring it to the WBI criteria for the developed countries it is weak. Considering the ILI index, according to AWWA, the state of water supply system in the analysed years 2007-2015 is weak. The infrastructure leakage index ILI in Polish cities varies, on average, at the level from 3,13 to 16,62 [4], on the basis of which it can be concluded that analysed water network is at satisfactory level. The determined values of the ILI correspond to national trends - for comparison the $I L I$ index for other water supply system ranged from 4,3 to 5,8 [11, 13]. The $N R W B$ index in $2007-2015$ ranges from $8,57 \%$ to $28,29 \%$, while the $R L B$ index was at the level of $12,51-16,67 \mathrm{~m}^{3} \cdot \mathrm{km}^{-1} \cdot \mathrm{d}^{-1}$ and also from 452,07 to $631,49 \mathrm{dm}^{3} \cdot \mathrm{d}^{-1} \cdot \mathrm{PW}^{-1}$.

\section{Conclusions}

The analysis of water losses and the determination of the unitary water loss indicators allow to perform detailed assessment of the state of operating water supply network. It can be indicated that there was no clearly visible downward trend or growth in the calculated indices. The unitary water loss indicator in the analysed time remains at a constant level. It should be noted that taking actions aiming at reducing water losses directly affect the financial results of the water company.

\section{Literature}

[1] Dohnalik P. Straty wody w miejskich sieciach wodociągowych. Wydawnictwo Polskiej Fundacji Ochrony Zasobów Wodnych. Bydgoszcz 2000.

[2] Hirner W., Lambert A.. Losses from Water Supply Systems: Standard terminology and recommended performance measures, IWA, London 2000.

[3] Koral W. Metodyka obniżania poziomu przecieków w sieciach wodociągowych, Wodociągi - Kanalizacja, 6(28), 2006, s. 26-29. 
[4] Kwietniewski M., Rak J., Niezawodność infrastruktury wodociągowej i kanalizacyjnej w Polsce, PAN, Warszawa 2010.

[5] Mayer P. et al. AWWA Leak Detection \& Water Accountability Comittee Report. Residential End Uses of Water. AWWA Research Foundation, 1999.

[6] Pietrucha-Urbanik K., Studziński A., Analiza strat wody wodociągu krośnieńskiego. Gaz, woda i technika sanitarna, nr 10, 2012, s. 452-454.

[7] Rak J. Metoda planowania remontów sieci wodociągowej na przykładzie miasta Krosna, Czasopismo Inżynierii Lądowej, Środowiska i Architektury - Journal of Civil Engineering, Environment And Architecture. JCEEA, z. 61(1/2015), s. 225-232, DOI: $10.7862 / \mathrm{rb} .2014 .15$.

[8] Rak J.R. (red.): Metody oceny niezawodności i bezpieczeństwa dostawy wody dla odbiorców. Oficyna Wydawnicza Politechniki Rzeszowskiej, Rzeszów 2013.

[9] Rak J.: Wybrane zagadnienia niezawodności i bezpieczeństwa w zaopatrzeniu w wodę. Oficyna Wydawnicza Politechniki Rzeszowskiej, Rzeszów 2008.

[10] Rak J., Tchórzewska-Cieślak B.: Czynniki ryzyka w eksploatacji systemów zaopatrzenia w wodę. Oficyna Wydawnicza Politechniki Rzeszowskiej, Rzeszów 2007.

[11] Rak J., Trojnar D.: Analiza i ocena strat wody w wodociągu Łańcuta. Czasopismo Inżynierii Lądowej, Środowiska i Architektury JCEEA, z. 61(1/2014), s. 245-256. DOI: $10.7862 /$ rb.2014.1.

[12] Rak J.R., Tunia A. Analiza i ocena strat wody w wodociągu Rzeszowa. Instal, Teoria i Praktyka w Instalacjach, 5/2012, s. 42-45.

[13] World Bank Institute Performance. NRW Training Module 6, Performance Indicators, 2005.

\title{
OCENA FUNKCJONOWANIA SIECI WODOCIĄGOWEJ NA PODSTAWIE STRAT WODY
}

\begin{abstract}
Streszczenie
W pracy przedstawiono analizę funkcjonowania sieci wodociągowej na podstawie strat wody występujących w przykładowej sieci wodociągowej miasta. Przy wykorzystaniu otrzymanych danych eksploatacyjnych obliczono jednostkowe wielkości zużycia wody, a także ustalono podstawowe wskaźniki strat wody, które odniesiono do wartości wskaźników zalecanych min. przez AWWA. Na ich podstawie dokonano oceny stanu systemu wodociągowego. Wyznaczone jednostkowe wskaźniki objętościowe dotyczące strat wody utrzymują się na stałym poziomie. Jednostkowy wskaźnik strat wody dla lat 2007-2015 wyniósł średnio ok. $108 \mathrm{dm}^{3} \cdot \mathrm{M}^{-1} \cdot \mathrm{d}^{-1}$, jednostkowy wskaźnik wody wtłaczanej do sieci przyjmuje wartości od $459,1 \mathrm{dm}^{3} \cdot \mathrm{M}^{-1} \cdot \mathrm{d}^{-1}$ w 2007 roku do $402,9 \mathrm{dm}^{3} \cdot \mathrm{M}^{-1} \cdot \mathrm{d}^{-1} \mathrm{w}$ roku 2015 , co oznacza jego spadek na poziomie ok. $12 \%$. Jednostkowy wskaźnik wody sprzedanej waha się w zakresie od 288,9 do $419,5 \mathrm{dm}^{3} \cdot \mathrm{M}^{-1} \cdot \mathrm{d}^{-1}$. Wskaźnik ILI według kryterium WBI Banding System dla krajów rozwijających się ocenia stan wodociągów jako dobry. Wartość wskaźnika ILI dla wodociągów odpowiada tendencjom krajowym, które wynoszą od 3,13 do $16,52[3,8]$.
\end{abstract}

Słowa kluczowe: sieć wodociągowa, straty wody, wskaźniki strat wody

DOI:10.7862/rb.2016.217

Przestano do redakcji: 29.01.2016 $r$.

Przyjęto do druku: 30.11.2016r. 